\title{
"Financial inclusion: disrupted liquidity and redundancy of mobile money agents in Zimbabwe"
}

\begin{tabular}{|c|c|}
\hline AUTHORS & $\begin{array}{l}\text { Last Mazambani Dttps://orcid.org/0000-0003-4133-2418 } \\
\text { Tariro Juliet Rushwaya } \\
\text { Emmanuel Mutambara }\end{array}$ \\
\hline ARTICLE INFO & $\begin{array}{l}\text { Last Mazambani, Tariro Juliet Rushwaya and Emmanuel Mutambara (2018). } \\
\text { Financial inclusion: disrupted liquidity and redundancy of mobile money agents } \\
\text { in Zimbabwe. Investment Management and Financial Innovations, 15(3), 131- } \\
\text { 142. doi:10.21511/imfi.15(3).2018.11 }\end{array}$ \\
\hline DOI & http://dx.doi.org/10.21511/imfi.15(3).2018.11 \\
\hline RELEASED ON & Thursday, 16 August 2018 \\
\hline RECEIVED ON & Monday, 12 February 2018 \\
\hline ACCEPTED ON & Wednesday, 25 April 2018 \\
\hline LICENSE & $\begin{array}{l}\text { (c) EY-NG } \\
\text { This work is licensed under a Creative Commons Attribution-NonCommercial } 4.0 \\
\text { International License }\end{array}$ \\
\hline JOURNAL & "Investment Management and Financial Innovations" \\
\hline ISSN PRINT & $1810-4967$ \\
\hline ISSN ONLINE & $1812-9358$ \\
\hline PUBLISHER & LLC "Consulting Publishing Company "Business Perspectives" \\
\hline FOUNDER & LLC "Consulting Publishing Company "Business Perspectives" \\
\hline
\end{tabular}

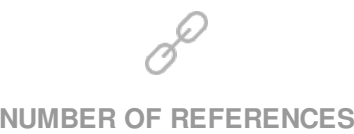

76

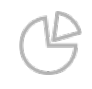

NUMBER OF FIGURES

0

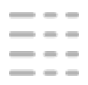

NUMBER OF TABLES

1

(C) The author(s) 2022. This publication is an open access article. 


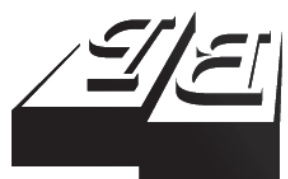

BUSINESS PERSPECTIVES

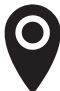

LLC "CPC "Business Perspectives" Hryhorii Skovoroda lane, 10, Sumy, 40022, Ukraine

www.businessperspectives.org

Received on: $12^{\text {th }}$ of February, 2018 Accepted on: $25^{\text {th }}$ of April, 2018

(C) Last Mazambani, Tariro Juliet Rushwaya, Emmanuel Mutambara, 2018

Last Mazambani, Doctoral Candidate, Graduate School of Business and Leadership, University of KwaZuluNatal, Durban, South Africa.

Tariro Juliet Rushwaya, Management College of Southern Africa, Cape Town, South Africa.

Emmanuel Mutambara, Senior Lecturer, University of KwaZuluNatal, Graduate School of Business and Leadership, Durban, South Africa.

\section{(ㄷ)(1) $(8)$}

This is an Open Access article, distributed under the terms of the Creative Commons Attribution-NonCommercial 4.0 International license, which permits re-use, distribution, and reproduction, provided the materials aren't used for commercial purposes and the original work is properly cited.
Last Mazambani (South Africa), Tariro Juliet Rushwaya (South Africa),

Emmanuel Mutambara (South Africa)

\section{FINANCIAL INCLUSION: DISRUPTED LIQUIDITY AND REDUNDANCY OF MOBILE MONEY AGENTS IN ZIMBABWE}

\begin{abstract}
Mobile money agents (MMAs) are the pedestal of inclusive finance by bringing financial services closer to unbanked people by offering them capabilities to move from cash to electronic money and vice versa. This function is effective in an environment where hard cash is in uninterrupted circulation. The aim of this paper is to investigate implications of cash liquidity challenges in Zimbabwe to the development of financial inclusion through MMAs in a rural set-up. Phenomenological in-depth interviews were conducted with MMAs. Due to national liquidity challenges, MMAs ceased to receive cash float support, limiting their cash-in and cash-out services. Pure agents were adversely affected, while those who operate retail goods services reported increased goods sales through mobile money point-of-sale payments. Consumers are restricted to deal in electronic funds in the cashless economy making the cash-in and cash-out function of MMAs redundant. MMAs need support to sustain their operations and recoup invested capital in infrastructure. Risk management strategies, including the principal-agent contracts that minimize the exposure of MMAs to disruption of the service are important. MMAs could form an association to lobby financial regulators for support, negotiation with principals, market research, political power and active participation of agents in deepening financial inclusion. Perhaps pure MMAs could improve their economic sustainability by diversifying their businesses.
\end{abstract}

\section{Keywords}

JEL Classification mobile money agents, liquidity challenges, principalagent contract, financial inclusion, unbanked, Zimbabwe

\section{INTRODUCTION}

Mass financial exclusion is a major problem in less developed economies, particularly in Africa (Mills, 2011; Pickens, 2009). Countries with disjointed and subsistence economies are likely to have most of their people outside mainstream financial markets (Viswanathan et al., 2010). As governments and policy makers fight for financial inclusion (Ivatury \& Mas, 2008), growth and opportunities, frugal disruptive engineering in cloud computing and mobile technology could be the transformational panacea in reaching millions of unbanked rural and low-income communities (Hughes \& Lonie, 2007; Mas \& Kumar, 2008; Duncombe \& Boateng, 2009; Morawczynski, 2010; Turnball, 2010). This development has resulted in the emergence of what is commonly referred to as cloud banking, cell phone banking, mobile money or mobile wallet (Turnball, 2010). These terms refer to all financial transactions performed using cell phone technology (Duncombe, 2012).

The growth of the service is riding on the back of massive investments in mobile phone technology and high mobile phone penetration rate in emerging markets (Donner, 2004; Orozco et al., 2007; The 
Economist, 2009; Tobbin, 2010). The service's resultant decentralization of banking services based on access to a handset and a "subscriber identity module" (SIM) has the capability of connecting every town and village thereby enabling previously unbanked poor people to send and receive money, transfer funds between accounts and pay bills from their cell phones (Heyer \& Mas, 2011; Dikit et al., 2012).

The introduction of mobile money services in low-income markets such as Kenya, the Philippines and Zimbabwe was received with wide adoption (Hidayati, 2011; Kalba, 2016). This phenomenal opportunity would not have been possible without the employment of MMAs to reach even the most remote and dispersed areas (Mas \& Morawczynski, 2009; Donovan, 2012). MMAs play a critical role in the distribution of mobile phone based financial services and is a game changer to financial inclusion (Duncombe, 2012). A MMA works on behalf of a principal to facilitate the distribution of mobile phone based financial services. These principals are traditionally banks or mobile network operators (Makanyeza, 2017).

The sustainability and survival of MMAs is critical to financial inclusion (Maurer et al., 2013). The main function, from which MMAs generate most of their fees or commissions, is cash-in and cash-out services. These commissions are very tinny and dependent on the values transacted. Given that poor people transact low value infrequently amounts, the commercial viability of mobile agents is always threatened (Duncombe, 2012; Ndlovu \& Ndlovu, 2013). The other administrative functions of opening mobile accounts and exchange of electronic float performed by agents on behalf of the principal are support services without significant monetary return (Heyer \& Mas, 2009). Liquidity management and the availability of cash float are, therefore, important for MMAs to offer cash-in and cash-out business services (Dermish et al., 2012; Mas \& Radcliffe, 2010).

Disruption in liquidity can have dire consequences to national payment systems including MMAs (Lawack, 2013). It is also important to note that technology based services like mobile money transfers are easily affected by market conditions and can adjust quite quickly. In the process, there could be beneficiaries and casualties from the changes. The mobile money transfer distribution channel in Zimbabwe has been disrupted by liquidity or cash shortages experienced in the country. There has been disruption of the flow of mobile money transfers due to cash shortages. Now, as mobile money substitute cash as means of payment (Dermish et al., 2012), pure MMAs have been found losing out, while groceries retailer agents that use point-of-sale mobile money payments have emerged as beneficiaries of these market changes. This seems to defeat the essence for which MMAs were introduced. In order to promote financial inclusion, an expansive MMA network is seen as a key value driver (Mas \& Morawczynski, 2009). Proximity of the agents to the market drives adoption and usage of the service (Medhi et al., 2009). MMAs were designed to dispense financial services closer to low-income communities than outreach of traditional banks (Zeng et al., 2017). Any disruption of this fundamental service means the served communities revert to the old system whereby they access cash from traditional banks located in urban areas (Mavhiki et al., 2015; Ndlovu \& Ndlovu, 2013).

The crippling cash shortage has disrupted the normal flow of cash in Zimbabwe. MMAs have ceased to receive cash float support thereby affecting their business operations. MMAs are being bypassed in the distribution of financial services threatening their economic sustainability. It is not clear how this development will affect the drive for financial inclusion. The study, therefore, explores the implications of the disrupted liquidity on financial inclusion as championed by MMAs. It would also be of interest to understand how the operations of the MMAs have been affected.

\section{Research problem}

In Zimbabwe, mobile banking agents have been successful in distributing the service to poor communities and creating entrepreneurship opportunities. However, the current liquidity challenges faced by the country have changed the fortunes of mobile banking agents. Due to liquidity challenges consumers are 
failing to cash-out their mobile money, but can purchase or make payments to traders and merchants. Cashless mobile money exchange is the main currency of business in Zimbabwe. As a result, cash-in and cash-out transactions are limited thereby cutting out mobile agents from the distribution channel.

\section{Research objectives}

The study specifically aims to gain insights into the implications of liquidity challenges to the development of financial inclusion through mobile agent banks. Further, the study will find out how mobile banking agents' business operations have been affected by liquidity challenges. Important conclusions and recommendations will be drawn for the development of the sector.

\section{Research questions}

The study seeks to address the research objectives by answering the following research questions:

- What are the implications of liquidity challenges to the development of financial inclusion through mobile banking agents?

- How are the operations of mobile banking agents affected by liquidity challenges?

- What are the potential responses to these challenges?

\section{Research significance}

MMAs are critical to deepening financial services towards the unbanked. The paper contributes to academic knowledge by shedding light on emergent developments in the critical area of financial inclusion. The study has connotations on principal-agent contracts and how risks could be minimized for both parties in the highly disruptive industry. The MMAs are constituted by some big nationwide retailers, but mostly by smaller tuck shops that only provide mobile money services and paraphernalia of other goods sold on behalf of the principal. These tuck shops are mostly owned by small-to-medium (SME) business operators who are required to put down capital to invest in the infrastructure (Mas \& Radcliffe, 2010). The waning of business has severe implications for these SMEs as it affects their personal and business economic sustainability. The study contributes by revealing how the operators view the future of their business and how their sustainability can be revived. These developments may as well have reshaped the value chain such that MMAs might need to start to search for alternative opportunities within and without the principal.

\section{LITERATURE REVIEW}

\subsection{Financial inclusion}

Financial inclusion can be defined as the "process of ensuring access to appropriate financial products and services needed by all sections of the society in general, and vulnerable groups such as weaker sections and low-income groups in particular, at an affordable cost, in a fair and transparent manner by regulated mainstream international players" (Kapoor, 2014). Financial inclusion is reached when all the citizens of a country have easy access to a wide variety of financial services at a cost that they can afford and the services meet their needs (Central Bank of Nigeria Report, 2012; Reserve Bank of Zimbabwe Report, 2015). This includes lessening the requirements for opening up bank branches, setting up ATMs and allowing local banking agents to be involved in carrying out bank transactions (Kapoor, 2014). It also includes removing of barriers and overcoming liabilities of the poor and the disadvantaged in the society so that they too have access to formal and protected financial services (Conroy, 2005). Financial regulators have been accommodative and flexi- 
ble to the free evolution of inclusive finance models including the deployment of MMAs (Lawack, 2013). Inclusion of a country's citizens into the formal financial services contributes to reduction of poverty and economic growth through mobilization of savings for productive use, allocating capital funds efficiently and managing risks thereby reducing disparities and eradicating poverty (Chakravarty \& Pal, 2013; De Koker \& Jentzsch, 2013; Kapoor, 2014). The accessibility of mobile phone technology brought a sense of hope that the unbanked masses could have access to financial services (Heyer \& Mas, 2011; Ivatury \& Mas, 2008; Chandra et al., 2010; Nel \& Raleting, 2012). The number of mobile banking agents has been an important value driver and a key element in the delivery of mobile money services (Bangens \& Soderber, 2008; Alampay \& Bala, 2009). Agents interact with consumers for cash-in and cash-out services and disseminated important banking information to mostly low-literacy and low-income communities. The wide adoption of mobile money service has been hinged on the proximity of MMAs to the people mostly in areas that were excluded and neglected by traditional financial institutions (Medhi et al., 2009). The combination of a widely distributed mobile phone technology and widespread MMAs makes financial inclusion possible (Peruta, 2018; Duncombe, 2012).

\subsection{Liquidity challenges in Zimbabwe}

Zimbabwe runs a dollarized economy where a multiple of international and regional currencies have been adopted as legal tender since 2009 (Sikwila, 2013). The US dollar is the main banking and trading currency (The Economist, 2013). Zimbabwe cut an isolated country from economic sanctions without financial support from multi-lateral financial institutions (Noko, 2011). As a net importer with weak productive capacity, high recurring government expenditure and no balance of payment support, Zimbabwe's liquidity challenges were always lurking. In no time after dollarization, the country started to face shortages of US dollar hard cash in circulation. The Reserve Bank of Zimbabwe issued a bond note, which is a surrogate currency, to ease the circulation of cash. The bond note is pegged at par with the US dollar, but from inception, it was never fully accepted by the public (Africa Research Bulletin, 2017).
However, the continued shortage of the US dollar from the official market escalated the emergence and flourishing of the black market. As most of the liquidity is now in the informal market, illiquid financial institutions merely facilitate electronic transactions. The situation is dire for MMAs who are positioned at the tail end of the value chain of money distribution. In fact the principals have ceased to support MMAs with any kind of liquidity support. Without cash floats, mobile money face liquidity risk which threatens their economic survival (Chiteli, 2013).

\subsection{Mobile money in Zimbabwe}

Mobile money platforms allow clients to perform various functions such as transfer of funds and payments for goods and services using a cell phone (Maurer et al., 2013). Mobile money is an important solution to financial exclusion (Ndlovu \& Ndlovu, 2013). With the cash-in and cash-out services through the agents or cash merchants, there has been a rapid increase in people using mobile money transfers (Mavhiki et al., 2015). Mobile money has provided opportunities for individuals to conduct financial transactions without being a bank account holder (Suarez, 2016). Mobile money transfers in Zimbabwe have been conducted through the use of agents. Mobile network operators (MNOs) are the main operators of mobile money in Zimbabwe and they have been using their mobile networks and access to subscribers to the exclusion of traditional banks (Mavhiki et al., 2015). Banks and MNOs only started to collaborate and promote technology and bank systems inter-operation ability after liquidity challenges. Customers can now transfer funds between their mobile wallets and traditional bank accounts. This is a great development in the advancement the financial markets born as a necessity to the cash challenges. It would appear that mobile phone technology has not yet been fully explored, with the cooperation of actors, it can champion the financial sector development (Marumbwa, 2014).

\subsection{Agent banking}

An agent bank acts on behalf of a principal such as a bank or cellular network operator to process financial transactions such as depositing, withdrawal, transfer of funds, and payment of bills 
(Omigie et al., 2017). Agents play a crucial role in activating customers. These agents make it possible through demonstrations for these new customers to transact and they also contribute to retaining them. They verify the identity of the customers when they sign up and in all subsequent transactions. The success of mobile money services is greatly dependent on the quality of the agent networks (Argent et al., 2013; Vutsengwa \& Ngugi, 2013). Agents are usually individuals with social capital and business relationships with potential clients for mobile money in their communities (Maurer et al., 2013). Local MMAs have been instrumental in extending financial services to the unbanked rural and remote areas, thereby promoting financial inclusion (Ndlovu \& Ndlovu, 2013; Zeng et al., 2017). Liquidity management and availability of cash float is critically important for agent banks to perform their cash-in and cashout function. Failure to secure cash would lead to customers to bypassing them. As commissions from cash-in and cash-out are their main revenue source, this has a negative connotation on the economic sustainability of their business.

\subsection{Agent banking challenges}

The prime function of MMAs is to help mobile money customers move from cash to electronic deposits and vice versa. Performing this function effectively requires adequate flow of cash float to meet withdrawal demands of customers while retaining sufficient electronic balances to facilitate conversions. Agents should have sufficient amounts of cash to allow transactions to take place as and when customers want to. Failure to do so results in customers perceiving the service as unreliable and this can lead to the diminishing reputation of the service provider (Maurer et al., 2013; Afande \& Mbugua, 2015). Advancement in inter-operationability between mobile money platforms and traditional bank accounts has given customers the power to self-serve (Omigie et al., 2017). Customers can now self-replenish their mobile accounts thereby bypassing MMAs. It is paramount to note that the continued infusion of technology will broaden the potential of financial markets and empower customers. Inevitably, there will be frequent disruptions to the distribution of technology based financial services (Marumbwa, 2014). The future of MMAs could be hinged on broadening value added financial services rather than the current transactional services (Zeng et al., 2017).

\subsection{Agent banking benefits}

Combined with agent banking, the mobile phone based banking channels created more benefits than disadvantages to the financial market and the newly banked public (Buku \& Meredith, 2013). MMAs provide a better service to the customers in the form of less waiting time, higher market decentralization and democratization of banking services by making it available to poor communities (Zeng et al., 2017). The new distribution channels are more cost-effective such that the general public transact at a fraction of the cost. This ultimately leads to lower costs to the consumer (Mols, 2001; Campbell \& Frei, 2010). The new mobile money channels might lead to a growth in the customer base as technology becomes more and more accessible to clients. Agents have further influence on the adoption of both mobile phones and mobile money in remote places. The MMA channels provide convenience, transactional efficiency, choice and access at competitive prices and returns (Birch \& Young, 1997; Jack \& Suri, 2014; Blumenstock et al., 2015). MMAs reduce the cost of transaction as they reduce the distance to the bank and minimize travel (Marumbwa, 2014). Ndlovu and Ndlovu (2013) observed that mobile agents were impactful as most rural residents have reduced their travel to urban areas for the sole purpose of accessing banking services. The technology used delivers quickly. The poor live at the margin, hence, the speed of mobile transactions becomes beneficial for them (Eijkman et al., 2010).

Due to exogenous market developments straining market liquidity, the intermediation role of the MMA has been obliterated as customers can self-service by linking bank accounts and mobile accounts for self-replenishing e-funds. It would therefore be of interest to understand through an empirical study how these developments impacted the functions of the MMAs and the development of financial inclusion. The viewpoints of the agents are invaluable in understanding the evolving circumstances. The following section looks at the methodology applied before discussing the results of the study. In the last section, conclusions and recommendations of the study are drawn. 


\section{METHODOLOGY}

Financial exclusion is often a phenomenon of the rural areas that are avoided by traditional financial institutions (Sarma \& Pais, 2011). In light of that, the study was carried out in a rural environment at Jerera business center under the administration of Zaka Rural District Council in Masvingo province, Zimbabwe. The district is found southwards of Harare in a drought prone area whose main business activity is subsistence farming. The business center was selected on the basis of convenience and lack of investment by traditional financial institutions. As recommended by Creswell (2014), a phenomenological research approach was used to understand the lived experiences of MMAs. Data were collected through unstructured qualitative in-depth face-to-face interviews with senior managers, experienced employees and entrepreneurs operating mobile money agency. The interviewees were selected at the rural business center using convenience sampling. The interviews lasted for approximately 45 minutes. The interviews were stopped after reaching data saturation. In total, six interviews were conducted providing rich and thick data. The interviewees had cumulative experience of 11 years of operating mobile money agency business. The sample was equally represented in terms of gender representation. The characteristics of the respondents are summarized in Table 1 below.

The respondents have deep customer-faced experience as mobile agents. Their accounts of the developments in the sector are first-hand and authentic. The respondents were relatively young and had strong views about the business potential of mobile money and how the liquidity crunch had negatively impacted on their network of relationship they had created over time. One of the respondents who had substantially invested in infrastruc- ture for the agent bank was quite emotional at the possibility of running into financial difficulties due to lack of support from the principal. Data from the interviews conducted were recorded and analyzed by the researcher.

\section{DISCUSSION OF RESULTS}

\subsection{Principal-agent relationship}

MMAs reported that the principals are very supportive and quick to resolve any challenges agents may face on the electronic platform. The principals are said to attend to queries in a timely manner. There are monthly meetings where representatives of the principals engage with agents to discuss operational issues. Some of the topical proposals in these meetings include the adoption of the South African Rand as one of the currencies on the mobile money platform. MMAs believe that the introduction of the Rand could solve the liquidity challenges. However, they are not too sure of what support they will get from the principals. One interviewee summed it up by saying, “...they used to support us in all our initiatives but we are not too sure if they will attend to this request...." The request is actually beyond the control of the MNOs as it is the prerogative of the central bank of the country.

The researchers made unique observations that while the principals provide operational support, they unfortunately do not advise agents of the potential risks of the trade. In fact, principals minimize the risks they were exposed to, while they leave agents exposed to the vagaries of business risk. One of the interviewees invested in a fully-fledged banking kiosk which cost him a fortune. Unfortunately, by the time he finished constructed the kiosks, the liquidity crunch was already biting. It would be im-

Table 1. Interviewee characteristics

\begin{tabular}{|c|c|c|c|c|}
\hline $\begin{array}{c}\text { Code of } \\
\text { interviewee }\end{array}$ & Employment status & Gender & Experience as MMA & Operations \\
\hline MA1 & Employee & Female & 0.5 & Pure agent \\
\hline MA2 & Entrepreneur & Male & 1 & Pure agent \\
\hline MA3 & Entrepreneur & Male & 3.5 & Pure agent \\
\hline MA4 & Manager & Female & 2 & Retailer groceries \\
\hline MA5 & Manager & Male & 2 & Retailer groceries \\
\hline MA6 & Entrepreneur & Female & 2 & Retailer hair pieces \\
\hline
\end{tabular}


portant if financial education can also be extended to agents so that they are fully aware of the potential risks that could affect their business before contracting. The interviewee felt neglected by the principal. The challenge is that big corporates may dictate the conditions of the contract without allowing agents to fairly ask for improved conditions. Perhaps this is a learning point for agents to organize a self-empowerment association that stand for the advancement of all banking agents.

\subsection{Disrupted liquidity support}

The mobile bank agents interviewed act on behalf of mobile network operators (MNOs) such as Econet, Netone and Telecel. They generally highlighted that they were receiving support from their principals through regular discussion meetings and workshops that are utilized to interactively address challenges and opportunities (Sanchez \& Ricart, 2010). All the MMAs decried lack of liquidity support from MNOs and bigger banks ever since the beginning of liquidity challenges in the country. They pointed out that MNOs never used to support them with advance liquidity assistance, but would avail cash float by gnashing the agent's electronic account with the MNO. MNOs, however, stopped providing this service when the nation started to face liquidity challenges. Some noteworthy replies from the interviewees "....the principal used to distribute cash to us but stopped when cash was a problem because of liquidity challenges..." Another respondent said, "...In 2014 we used to get cash from the banks but nowadays you just use your own resources..." A relatively young respondent note that "....our business is not doing well because of cash circulation problems. If agents were allowed to access cash float for liquidity purposes just like banks, our fortunes would improve... We used to get rotational cash allocations which the principal has since stopped. Now there is virtually no cash float support for agents...."

\subsection{Redundancy of MMAs}

MMAs pointed out that without cash float, their main function of cash-in and cash-out which brings most of their revenue is redundant. They further complained that the continue lack of liquidity challenges will lead them to lose their customers and some relationships they had created. Mobile agents created accessibility for even for civil servants working in rural areas. An interviewee commented that "...most civil servants in our community have mobile money accounts linked with their banks but we cannot serve them anymore because we do not have cash..... They now abscond classes to travel to banks in town in search of cash...." They highlighted this has caused a great inconvenience to the community which was now used to getting cash at their doorsteps. One agent highlighted that "...a lot of people were now doing mobile banking so the liquidity challenges have affect them severely..." The results are in live with the observation of Maurer et al. (2013) that the intensification of a broadly cashless economy would render MMAs redundant. Despite this setback, MMAs are critically required for deepening financial inclusion. The emergent distribution channels of mobile money, as a result of the redundancy of the MMAs, clearly have no development impact. The channels may not advance the interest of financial inclusion as they inconvenient and are removed from low-income communities. It would be in the interest of the industry to bring back MMAs into the loop.

\subsection{Business sustainability}

Mobile bank agents reported reduced business in cash-in and cash-out after market liquidity challenges. Consequently their cash-in and cash-out incentive or commission has drastically gone down due to reduced business. Pure agents reported that their cash-out activities are only limited to the amount they receive from cash-in or sales of other merchandise which they say is too little to sustain operations. Some agents suggested borrowing cash from friends and relatives to inject liquidity into the business. However, one of the interviewees retorted that borrowing cash is pointless as it will create headaches to get the money back. Agents with grocery stores reported that they hardly get cash-in transactions, but they offer $50 \%$ on the value of goods purchased for their clients to cash-out.

The interviewees were in agreement that when there are no cash shortages their mobile money agency business operations can cover operating costs and post a good profit. They noted that this is a major source of revenue for their business, hence, it is at the mercy of other developments such as the current disrupted cash circulation. Most of the 
interviewees note that competition is not even a problem to their viability for as long as they have sufficient cash flows.

\subsection{Business fortunes}

Pure MMAs are those that only provide mobile money services without additional business. Interviewees who offered this service complained that their business had been adversely affected by the cash shortages. Pure agents had more challenges because their business solely dependent on cash-in and cash-out. One pure agent noted that '......we use the little cash we make from selling products such as bulky airtime to do cash-out... otherwise if we do not have cash we just scale down". On the other hand, the interviewees who represented grocery retail shops reported that their customers and indeed their sales from mobile money payments are increasing. They however, bemoaned delayed service from the principal in terms of the supply of the specialized till slips supplied by the principal. One interviewee said that "...point-of-sale till roles using mobile money finish quickly and we do not get them on time..."

\subsection{Future expectations}

The interviewees remain optimistic that their future business fortunes will improve once the na- tionwide cash shortage is addressed. This was notable by a common response that "......once we get cash, our problems are solved”. They also remained positive that their principals will provide them with support to get more additional services to sell such as helping the public to pay for prepaid subscription television channels, selling prepaid electricity tokens, and distribution of bulky airtime. They also hope that they will find solutions in their monthly meetings with principals. The agents are also anticipative that if the South African Rand that has been recently introduced on the mobile payment system is fully adopted, it might improve the business situation.

Though they spoke of scaling down operations, none of them perceived the market developments as long-term or one that can disrupt the distribution of mobile money forever. They view the liquidity challenge as temporal. They also remained simplistic on their assessment that when the business environment improves their business would be resuscitated. Individually, MMAs lack the capacity to conduct research on the implications of these challenges on the future of their operations. Their heavy reliance on the principals to find solutions leave them exposed to the whims or arbitrary decisions by the principals. There might be need to build negotiating or contractual clout through organizing themselves into an association.

\section{CONCLUSION}

This study captured the viewpoints of mobile agency operators. It is interesting to note that all the interviewees expressed great optimism that their fortunes will improve once the cash situation improves. Perhaps, it is because this change in the mobile money market is induced by factors outside the direct evolution of the service. However, technology based products may not revert to old practices. Even if they do, the amount of business may not be as great as it was before.

Low-income people live in a predominantly cash economy; they cannot save or make payments remotely (Medhi et al., 2009). The obliteration of the function of banking agents appears inimical to financial inclusion. The number of functional agents is a key value driver in mobile money. MMAs are of the view that if banking is to be inclusive of everyone, they should be supported through daily allocation of cash float just like other banks. Mobile agents believe that to survive they should be subcontracted to perform more value adding services that improve their earnings.

Agents were disrupted unexpected after undertaking huge investments in infrastructure. Perhaps, this has a bearing on the structure of principal-agent contracts in technology based services prone to disruption. The wholesome transfer of risk by principals to agents in building banking infrastructure may need to be reviewed in order to minimize the risk exposure to agents. As reported by Mas and Radcliffe 
(2010), pure agents in rural areas are run by unsophisticated survivalist entrepreneurs, some who may hardly comprehend the level of risk exposure they could suffer. Principal-agency contracts that ensure that risks to both parties are shared and minimized would ensure that there are no losers in the event of disruption.

MMAs promoted a cash economy which stifled the adoption of electronic payments especially in rural areas. The liquidity challenges affected mostly the rural economy because it is traditionally based on cash transactions (Medhi et al., 2009). The induced behavioral changes which pushed rural people to venture into unfamiliar areas of electronic transactions for a low-literacy people. However, the liquidity crunch in a way has increased the adoption of mobile payments by people from rural communities. The cash shortages have actually forced rural consumers to adopt electronic payment systems. Liquidity challenges, would appear to increase the use and adoption of plastic and electronic money by the public albeit with resistance.

Mobile money principals recruit or outsource mobile money agency services from SMEs as well as big retail chain stores. The liquidity challenges grossly prejudiced SMEs while it transferred business to big corporations. It can be deducted that this has a negative connotation on the development of entrepreneurship. The liquidity crunch is a serious risk factor at the agent level which requires proactive action from financial regulators. The current scenario where only big banks with urban branches receive cash floats is not only an affront to the democratization of financial markets but a perpetuation of exclusionary business practices against the poor and powerless. It is an infringement on the freedoms of poor people who have to travel long expensive distance to stand in long queues to access their money.

The technology sector is prone to disruptions, some intentional and others emergent (Blumenstock et al., 2015). In general, agents can take a pro-active approach to diversify their business as a measure to guard their economic sustainability. This is done in order to evade redundancy of the organization and its employees. The agents should not wait to be forced out of business by their competitors or changes in the distribution channels (Mols, 2001). However, this is only possible if there is top management support that spots customer needs (Mols, 2001). Literature on distribution channels has posited that in order to avoid obsolescence, it might be necessary to have different products serving different customer segments (Rangan et al., 1992).

\section{RECOMMENDATIONS}

It is high time that pure agents consider diversifying into other businesses. With rapid technological changes, some services will evolve while others cease to exist. Well diversified businesses operations will ensure continued economic sustainability of MMAs. Alternatively, the principal in the agency relationship may look for other avenues to utilize the agents in their value chains. Agents also need to empower themselves and the communities they serve by possibly forming an association that can lobby for the full liquidity support of agents in rural areas considering the critical role they play in financial inclusion. The association could also help with negotiating leverage in drawing principal-agent contracts, as well as conducting scientific research to help agents minimize risks while capturing opportunities.

The situation in Zimbabwe might be unique in the sense that the adoption of mobile money as the anchor method of payments was not voluntary. Liquidity challenges created opportunities for increased use of plastic and electronic money. Technology based products are exposed to rapid change. Without the physical cash, MMAs are redundant. Consumers are now dealing directly with retailers (distribution channel has been reduced). Financial regulators and institutions should promote the use of plastic and cell phone money. 
The national payment systems should be developed to be inclusive of some transactions that are still cash based. Many service providers such as public transport operators and other petty transactions still insist on cash payments. The national payment system has not sufficiently developed to include these transactions. The frequency of public transactions requires payment solutions such as using near-field-technology or improvement of mobile money.

The current mobile money services are still transactional services like cashing in and out. They have only provided access to a mere mobile 'bank account' without any added value that improves the wellbeing of previously unbanked people. Perhaps this is the time that mobile agents could be turned towards higher order financial services such as advancing loans, savings and investments. They can also be engaged in expanding microfinance services like micro-insurance in rural areas.

While the fortunes of MMAs are waning due to cash shortages, there is an increased use of electronic payment methods as many people are driven to adopt mobile money as the anchor currency of business. This development has caused increased business for the principals albeit at the expense of MMAs as mobile money transactions are confined to electronic transfers between consumers and retailers, and person-to-person electronic transfers. There might be need to relook at the principal-agent contracts to ensure that the vulnerable agents are protected from potential risks.

Financial institutions and monetary authorities might capitalize on this window of opportunity to strengthen the adoption and acceptance of electronic money in the country. Monetary authorities may improve the national payment system to ensure that electronic payment methods become the method of first choice. Faced with a dollarized economy suffering from repeated currency crises, some recommendations suggest that financial markets could be innovative enough to develop and adopt a cryptocurrency that can be used to trade in the cashless economy (Raymaekers, 2015).

\section{REFERENCES}

1. Aduda, J., \& Kingoo, N. (2012). The Relationship Between Electronic Banking and Financial Performance among Commercial Banks in Kenya. Journal of Finance and Investment Analysis, 1(3), 99-118.

2. Afande, F. O., \& Mbugua, S. W. (2015). Role of Agent Banking Services in Promotion of Financial Inclusion in Nyeri Town, Kenya. Research Journal of Finance and Accounting, 6(3), 2222-2847. Retrieved from https://www.iiste. org/Journals/index.php/RJFA/article/view/19956

3. Africa Research Bulletin (2017). Zimbabwe: Bond Note Chaos. Africa Research Bulletin: Economic, Financial and Technical Series, 53(11), 21503-21504.

4. Alampay, E., \& Bala, G. (2009). Mobile 2.0: M-money for the BoP in the Philippines. Annenberg School for Communication and Journalism, 6(4), 77-92.

5. Argent, J., Hanson, J. A., \& Gomez, M. P. (2013). The regulation of mobile money in Rwanda. s.l.: International Growth Centre.

6. Bangens, L., \& Soderber, B. (2008). Mobile Banking - Financial Services for the Unbanked? s.l.: The Swedish Program for ICT in Developing Regions (SPIDER).

7. Bhasera, C. H., \& Dhliwayo, K. (2013). Impact of product/ service characteristics on the rate of adoption of an innovation: A case of Ecocash mobile services in Chipinge District, Zimbabwe. Journal of Business and Management, 13(6), 26-32.

8. Birch, D., \& Young, M. A. (1997). Financial services and the Internet - what does cyberspace mean for the financial services industry? Internet Research: Electronic Networking Applications and Policy, 7(2), 120-128.

9. Blumenstock, J. E., Callen, M., Ghani, T., \& Koepke, L. (2015). Promises and Pitfalls of Mobile Money in Afghanistan:
Evidence from a Randomized Control Trial. Proceedings of the Seventh International Conference on Information and Communication Technologies and Development. ACM. http://dx.doi. org/10.1145/2737856.2738031

10. Bucklin, L. P. (1966). A Theory of Distribution Channel Structure. Berkeley: IBER Special Publications.

11. Buku, M. W., \& Meredith, M. W. (2013). Safaricom and M-Pesa in Kenya: Financial Inclusion and Financial Integrity. Washington Journal of Law, Technology and Arts, 8(3), 375-400. Retrieved from http:// digital.law.washington.edu/dspacelaw/handle/1773.1/1204

12. Campbell, D., \& Frei, F. (2010). Cost Structure, Customer Profitability, and Retention Implications of Self-Service Distribution Channels: Evidence from Customer Behavior in an Online Banking Channe. Management Science, 56(1), 4-24.

13. Central Bank of Nigeria Report (2012). National financial inclusion 
strategy. Abuja: Central Bank of Nigeria.

14. Chagonda, T. (2012). Teachers' and Bbank Workers' Responses to Zimbabwe's Crisis: Uneven Effects, Different Strategies. Journal of Contemporary African Studies, 30(1), 83-97.

15. Chakravarty, S. R., \& Pal, R. (2013). Financial inclusion in India: An axiomatic approach. Journal of Policy Modelling, 35, 813-837.

16. Chandra, S., Srivastava, S. C., \& Theng, Y. (2010). Evaluating the Role of Trust in Consumer Adoption of Mobile Payment Systems: An Empirical Analysis. Communications of the Association for Information Systems (CAIS), 27(29), 561-588.

17. Chiteli, N. (2013). Agent Banking Operations as a Comparative Strategy of Commercial Banks in Kisumu City. International Journal of Business and Social Sciences, 4(13), 306-324.

18. Conroy, J. (2005). APEC and financial exclusion: Missed opportunities for collective action? Asia-Pacific Journal, 12(1), 53-79.

19. Creswell, J. W. (2014). Research Design: Qualitative, Quantitative, and Mixed Methods Approaches (4th ed.). California: SAGE Publications, Inc.

20. De Koker, L., \& Jentzsch, N. (2013). Financial inclusion and financial integrity: Aligned incentives? World Development, 44, 267-280.

21. De Koker, L., \& Jentzsch, N. (2013). Financial inclusion and financial integrity: Aligned incentives? World Development, 44, 267-280.

22. Dermish, A., Kneiding, C. Leishman, P., \& Mas, I. (2012) Branchless and Mobile Banking Solutions for the Poor: A Survey of the Literature. Innovations, 6(4), 81-98.

23. Dikit, S. V., Shringarpure, A. A., \& Pathan, F. N. (2012). Strategies to Make Mobile Banking Popular in India. Advances in Management, 5(13), 6 .

24. Diniz, E., Birochi, R., \& Pozzebon, M. (2011). Triggers and Barriers to Financial Inclusion: The use of ICT-based Branchless
Banking in an Amazon County. Electronic Commerce Research and Applications, 11(5), 484-494.

25. Donner, J. (2004)

Microentrepreneurs and Mobiles: An Exploration of the Uses of Mobile Phones by Small Business Owners in Rwanda. Information Technologies and International Development, 2(1), 1-21.

26. Donovan, K. (2012). Mobile Money for Financial Inclusion. Information and Communications for Development, 61(1), 61-73.

27. Duncombe, R. (2012). An Evidencebased Framework for Assessing the Potential of Mobile Finance in SubSaharan Africa. Journal of Modern African Studies, 50(3), 369-395.

28. Duncombe, R., \& Boateng, R. (2009). Mobile Phones and Financial Services in Developing Countries: A Review of Concepts, Methods, Issues, Evidence and Future Research Directions. Third World Quarterly, 30(7), 1237-1258.

29. Eijkman, F., Kendall, J., \& Mas, I. (2010). Bridges to Cash: the retail end of M-PESA. Savings and Development, 34(2), 219-252.

30. Heyer, A., \& Mas, I. (2009). Seeking Fertile Ground for Mobile Money. Retrieved from https://www.gsma. com/mobilefordevelopment/ wp-content/uploads/2012/03/fertile_grounds_mobile_money55.pdf (accessed on January 16, 2018).

31. Heyer, A., \& Mas, I. (2011). Fertile Grounds for Mobile Money: Towards a Framework for Analysing Enabling Environments. Bill and Melinda Gates Foundation.

32. Hidayati, S. (2011). Cash-in and Cash-out Agents for Mobile Money in Indonesia. Innovations, 6(4), 117-123.

33. Hughes, N., \& Lonie, S. (2007). M-PESA: Mobile Money for the "Unbanked" Turning Cellphones into 24-Hour Tellers in Kenya. Innovations, 2(1-2), 63-81.

34. Ivatury, G., \& Mas, I. (2008). The Early Experience with Branchless Banking. s.l.: CGAP.

35. Jack, W., \& Suri, T. (2014). Risk Sharing and Transactions Costs: Evidene from Kenya's Mobile Money Revolution. American Economic Review, 104(1), 183-223.
36. Kalba, K. (2016). Explaining the Mobile Money Adoption-Usage Gap. Communications and Strategies, 103, 113-143. Retrieved from https:// web.b.ebscohost.com/abstract?direc $\mathrm{t}=$ true \&profile $=$ ehost\&scope $=$ site \& authtype $=$ crawler\&jrnl $=24911275 \&$ $\mathrm{AN}=119864955 \& \mathrm{~h}=\mathrm{OqP} 2 \mathrm{IaF} 5 \mathrm{Bso}$ Fb3o6XCdnNH\%2b7\%2bjyH817\%2 f0LZM8hmfi0KgcGpJWT8IKqIfsX sZh1akRddllexmhkt1\%2fGW2JG7 XA\%3d\%3d\&crl=c\&resultNs=Adm inWebAuth\&resultLocal=ErrCrlNo tAuth\&crlhashurl=login.aspx\%3fdir ect $\% 3$ dtrue $\% 26$ profile $\% 3$ dehost $\% 2$ 6scope $\% 3$ dsite\%26authtype\%3dcra wler\%26jrnl\%3d24911275\%26AN\% 3d119864955

37. Kapoor, A. (2014). Financia inclusion and the future of the Indian economy. Futures, 56, 35-42.

38. Lawack, V. A. (2013). Mobile Money, Financial Inclusion and Financial Integrity: The South African Case. Washington Journal of Technology \& Arts, 8(3), 317-345.

39. Mago, S., \& Chitokwindo, S. (2014) The Impact of Mobile Banking on Financial Inclusion in Zimbabwe A Case of Masvingo Province. Mediterranean Journal of Social Sciences, 5(9), 221-230.

40. Makanyeza, C. (2017) Determinants of Consumers' Intention to Adopt Mobile Banking Services in Zimbabwe. International Journal of Bank Marketing, 35(6), 997-1017.

41. Marumbwa, J. (2014). Exploring the Moderating Effects of SocioDemographic Variables on Consumer Acceptance and Use of Mobile Money Transfer Services (MMTs) in Southern Zimbabwe. American Journal of Industrial and Business Management, 4, 71-79. Retrieved from https://file.scirp.org/ pdf/AJIBM_2014021110394562.pdf

42. Mas, I., \& Radcliffe, D. (2010). Mobile payments go viral: M-PESA in Kenya. The Capco Institute Journal of Financial Transformation, 32, 169-182.

43. Mas, I., \& Kumar, K. (2008). Bank on Mobiles: Why, How, for Whom? s.l.: CGAP.

44. Mas, I., \& Morawczynski, O. (2009) Designing mobile money services lessons from M-PESA. Innovations, 4(2), 77-91. 
45. Maurer, B., Nelms, T. C., \& Rea, S. C. (2013). 'Bridges to Cash': Channeling Agency in Mobile Money. Journal of the Royal Anthropological Institute, 19, 52-74.

46. Maurer, B., Nelms, T. C., \& Rea, S. C. (2013). Bridges to cash: channelling agency in mobile money. Journal of Royal Anthropological Institute, 19, 52-74.

47. Mavhiki, S., Nyamwanza, T., \& Shumba, L. (2015). Impact of mobile banking on traditional banking practices in Zimbabwe. International Journal of Economics, Commerce and Management, 3(1), 1-13. Retrieved from http:// ijecm.co.uk/wp-content/uploads/2015/01/3129.pdf

48. Medhi, I., Ratan, A., \& Toyama, K. (2009). Mobile-banking Adoption and Usage by Low-literate, Lowincome users in the Developing World. Internationalization, Design and Global Development, 485-494.

49. Meuter, M., Ostrom, A., Roundtree, R., \& Bitner, M. J. (2000). Selfservice technologies: Understanding customer satisfaction with technology-based service encounters. Journal of Marketing, 64(3), 50-64.

50. Mills, G. (2011). Why Africa is Poor and What Africans can do about it. s.l.: Penguin Books (South Africa).

51. Mols, N. P. (2001). Organizing for the effective introduction of new distribution channels in retail banking. European Journal of Marketing, 35(5/6), 661-686.

52. Mols, N. P., Bukh, P. N., \& Nielsen, J. F. (1999). Distribution channel strategies in Danish retail banking. International Journal of Retail and Distribution Management, 27(1), 37-47.

53. Morawczynski, O. (2010). Examining the Adoption, Usage and Outcomes of Mobile Money Services: The Case of M-PESA in Kenya. s.l.: Science and Technology Studies, The University of Edinburgh.

54. Ndiwalana, A., Morawczynski, O., \& Popov, O. (2010). Mobile Money use in Uganda: A Preliminary Study, s.l.: Unpublished Paper.

55. Ndlovu, I., \& Ndlovu, M. (2013). Mobile banking the future to rural financial inclusion: Case study of
Zimbabwe. Journal of Humanities and Social Science, 9(4), 70-75.

56. Nel, J., \& Raleting, T. (2012). Gender Differences in Low-income Nonusers' Attitude Towards Wireless Internet Gateway Cellphone Banking. South African Journal of Business Management, 43(3), 51-63.

57. Noko, J. (2011). Dollarization: The Case of Zimbabwe. Cato Journal, 31(2), 339-365.

58. Omigie, N. O., Zo, H., \& Rho, J. J. (2017). Customer Preadoption Choice Behavior for M-PESA Mobile Financial Services: Extending the Theory of Consumption Values. Industrial Management and Data Systems, 117(5), 910-926.

59. Orozco, M., Jacob, K., \& Tescher, J. (2007). Card-based Remittances: A Closer Look at Supply and Demand (Mimeograph). s.l.: The Center for Financial Services Innovation.

60. Paelo, A. (2014). Mobile money: Taking on banks. s.l.: CCRED Review.

61. Peruta, M. D. (2018). Adoption of Mobile Money and Financial Inclusion: A Macroeconomic Approach through Cluster Analysis. Economics of Innovation and New Technology, 27(2), 154-173.

62. Pickens, M. (2009). Window on the Unbanked: Mobile Money in the Philippines. Retieved from https:// openknowledge.worldbank.org/ bitstream/handle/10986/9488/567 240BRI0CGAP1le1Money1Philipp ines.pdf? sequence $=1$ (accessed on January 22, 2018).

63. Rangan, V., Menezes, M., \& Maier, E. (1992). Channel selection for new industrial products: a framework, method, and application. Journal of Marketing, 56(3), 69-82.

64. Raymaekers, W. (2015). Cryptocurrency Bitcoin: Disruption, Challenges and Opportunities. Journal of Payments Strategy and Systems, 9(1), 3046. Retrieved from http://www. ingentaconnect.com/content/hsp/ jpss/2015/00000009/00000001/ art00005

65. Reserve Bank of Zimbabwe Report (2015). Zimbabwe national financial inclusion strategy (2016-2020). Harare: Reserve Bank of Zimbabwe.
66. Sanchez, P., \& Ricart, J. E. (2010). Business Model Innovation and Sources of Value Creation in Low-income Markets. European Management Review, 7, 138-154.

67. Sarma, M., \& Pais, J. (2011). Financial Inclusion and Development. Journal of International Development, 23 613-628.

68. Sikwila, M. N. (2013) Dollarization and the Zimbabwe's Economy. Journal of Economics and Behavioral Studies, 5(6), 398-405.

69. Suarez, S. L. (2016). Poor people's money: The politics of mobile money in Mexico and Kenya. Telecommunications Policy, 40, 940-955.

70. The Economist (2009). Mobile Marvels, A Special Report on Telecoms in Emerging Markets. s.l.:s.n.

71. The Economist (2013). In Dollars they Trust; Zimbabwe after Hyperinflation. Retrieved from Academic OneFile: http://link.galegroup.com/apps/doc/A327557096/ $\mathrm{AONE} ? \mathrm{u}=$ unict\&sid=AONE\&xi $\mathrm{d}=$ bf007455 (accessed on January 24, 2018).

72. Tobbin, P. (2010). Modeling Adoption of Mobile Money Transfer: Consumer Behaviour Analysis, Kampala: Mobile4Development.

73. Turnball, S. (2010). How Might Cell Phone Money Change the Financial System? The Capco Institute Journal of Financial Transformation, 33-42.

74. Viswanathan, M., Sridharan, S., \& Ritchie, R. (2010). Understanding Consumption and Entrepreneurship in Subsistence Marketplaces. Journal of Business Research, 63, 570-581.

75. Vutsengwa, R. M., \& Ngugi, K. (2013). An assessment of the challenges facing commercial banks in sustainability of agency banking in Kenya: A case of commercial banks. International Journal of Economics and Finance, 1(2), 1-8.

76. Zeng, W., Bai, J., \& Shi, X. (2017). Development and Use of Rural Finance: A Case Study of Village A in Sichuan Province. Asian Agricultural Research, 9(6), 13-18. 